\title{
Impact of demographic, political and financial factors on municipal transparency: a dynamic panel approach
}

\begin{tabular}{|r|l|}
\hline Journal: & International Journal of Public Sector Management \\
\hline Manuscript ID & IJPSM-11-2019-0289.R3 \\
\hline Manuscript Type: & Original Article \\
\hline Keywords: & $\begin{array}{l}\text { Transparency, Local Government, Municipalities, Dynamic panel data } \\
\text { model }\end{array}$ \\
\hline \multicolumn{2}{|l}{} \\
\hline
\end{tabular}

\section{SCHOLARONE \\ Manuscripts}




\title{
Impact of demographic, political and financial factors on municipal transparency: a dynamic panel approach
}

\begin{abstract}
Purpose - This paper seeks to identify some of the most important drivers of Portuguese local government transparency in their activities over time. Recent literature on good governance has repeatedly identified transparency as central to promoting accountability, preventing corruption and mismanagement, and stimulating greater civic engagement. As local government is the main provider of many primary services to the population, evaluating its transparency is especially relevant given that misconduct or maladministration will have a strong impact on the population's well-being. Given increased diffusion of European good governance norms and practices, we believe the Portuguese case to be relevant across the EU.
\end{abstract}

Design/methodology/approach - We develop a dynamic panel data model to evaluate the simultaneous influence of both political and contextual variables on the Municipal Transparency Index (MTI) in 308 Portuguese municipalities during the period from 2013 to 2017 .

Findings - The results suggest support for previous studies that found increased internet enabled transparency in municipalities with low levels of indebtedness (per capita), are more highly populated, are governed by left-wing parties, demonstrating higher levels of financial efficiency. The urban/rural status, measured by population density, is not a significant predictor.

Originality/value - The paper seeks to confirm earlier analyses of these same data over a a longer period of years to substantiate the validity of those findings. This is important especially in the context of the political variable, to demonstrate it was not necessarily a particular collection of left-wing mayors, but that the relationship holds over time, across administrations, because the dataset covers two election periods. 
Keywords Transparency, Local government, Municipalities, Dynamic panel data model

Paper type Research paper

\section{Introduction}

Despite the growing scholarly and practitioner consensus that increasing the transparency and openness of government activity helps increase levels of trust and interest in local democratic governance, and decreases opportunities for corruption and mismanagement, recent studies suggest continued variation in the efforts of local governments to advance the goals of greater transparency. In the European context, a variety of international organizations and actors have converged with domestic political coalitions of stakeholders to press for greater norms of transparency and access to information in the public sector. From the adoption of Freedom of Information Acts at the national level, to joining the Open Government Partnership, European governments, from the national to the local, have rhetorically committed themselves to making more of what they do, more of what they decide, and more of what they spend and buy, available to the public in what scholars call "computer mediated" transparency, usually via local, regional, national government websites.

The march of the open government movement has generated a fair amount of scholarly work examining variation in existing levels of transparency, as well as trying to identify the factors that favour or impede continued progress. Initially, considerable effort was directed at developing ways to both identify what governments ought to be making available (via the internet and their municipal websites) and how best to measure or capture the degree to which they are making efforts to do so. Often working with the official national representatives of Transparency International, some studies from 
Slovakia (Sičáková-Beblavá et al., 2016), Spain (Araújo and Tejedo-Romero, 2016) and Portugal (da Cruz et al., 2016) have developed multi item indices of local/municipal government transparency, by examining municipal website content. While they differ in terms of their methodological complexity, each Municipal Transparency Index (MTI) defines transparency in a similar manner, "the publicity of all acts of government and their representatives to provide civil society with relevant information in a complete, timely, and accessible manner" (da Cruz et al., 2016, p. 872), or as the act of providing relevant, credible, timely, intelligible, and easily accessible information about the format, performance, and management of the public good (Transparency International - Portugal, 2017).

Several studies have examined the early rankings of Portuguese municipalities using the above referenced MTI including Batalha (2014), Tejedo-Romero and Araújo (2020), Tavares and da Cruz (2020), with some conflicting results and different methodologies. This article strives to resolve some of these earlier discrepancies, by analysing and furthering the understanding of the potential determinants of local transparency over a longer period of time (2013 to 2017). The purpose of this study is largely confirmatory. This research seeks to determine whether the following factors influence the level of transparency in Portuguese municipalities, as a function of their scores on the MTI over time: (i) the ideology of the governing party (mayor's party); (ii) the population size of the municipalities; (iii) the level of municipal debt per capita; (iv) the municipality's overall financial outlook; and (v) the population density of the municipalities. Its empirical contribution stems from examining factors prior scholars have identified as important over a longer (four year) period of time. This is especially important for the partisan variable, to demonstrate it was not necessarily a particular 
collection of mayors, but that the partisan relationship holds over time, and across administrations.

The paper proceeds with the following sections: a literature review and development of hypotheses, discussion of the methodological approach, analysis and presentation of the results, discussion of the relevant conclusions and avenues for future research.

\section{Literature review and hypothesis development}

\section{Theorizing Transparency and its Provision}

Access to information is now accepted as a fundamental right protected by national constitutions in many democratic countries (Cooper, 2004). Democracy must be open and transparent so that citizens have access to public information and can scrutinise their elected officials (Sjöberg, 2010). Indeed, transparency practices are particularly important in local authorities due to their close proximity to citizens. The OECD (2002) defines transparency as openness on policy intentions, formulation and implementation. Relatedly, Armstrong (2005) defines it as the access by the public to timely and reliable information on government decisions and performance, while for Alt et al. (2006) transparency refers to the degree to which citizens, the media and financial markets can observe the government's activities and the policy outcomes. In short, transparency can be viewed as the degree of access to information about the government, accessible and timely, to all relevant stakeholders (Kraay and Kaufmann, 2002).

Araújo and Tejedo-Romero (2016, p. 326) argue that the "literature about transparency is largely based on the explanations of agency theory and legitimacy theory". Indeed, agency theory is one of the most commonly used theoretical foundations for understanding the relationship between local policy and citizens, nowadays through 
digital instruments (Guillamón et al., 2016). Jensen and Meckling (1976) defined an agency relationship as a contract in which one or more persons (the principal) hire another person (the agent) to perform a service or job on their behalf. In this agency relationship, the principal delegates a certain decision-making authority to the agent. This relationship is characterised by the existence of a potential conflict because each party (the elected politician and the citizen/voter) intends to maximise his/her own interest. Here, transparency is the instrument used to ensure that the agent - acting on behalf of the principal through the delegation of powers - does not promote his/her own interests (Sičáková-Beblavá et al., 2016).

At the local level this is especially important, because, as observed by TejedoRomero and Araújo (2018, p. 528), "problems related to transparency are more frequent at the local level, as local politicians are usually more discrete when it comes to taking decisions." In this vein, social actors, such as NGOs, industry, or media, pressure elected officials to make available information that will allow them to hold politicians accountable (Grimmelikhuijsen and Welch, 2012). Berry et al. (2004) states that online disclosure practices are often implemented in response to external pressures, and Cuadrado-Ballesteros et al. (2014) highlight the role of media scrutiny and activity. Thus the density and organization of municipal civic life is thought to produce better, more responsive, and more transparent government (Putnam, 1993, Dowley, 2006).

An alternative conceptualization sees politicians and public sector actors proactively providing transparency as a means of achieving or bolstering their legitimacy in the eyes of their constituents (Curtin and Meijer, 2006). While the linkage is still contested (De Fine Licht et al., 2014), the argument is that savvy politicians will seek to make public their decision making processes in order to generate public support for their decisions because they knew enough in advance to influence the outcome, and therefore 
such actions will generate (even begrudging) respect for the outcome (Curtin and Meijer, 2006). Thus, public sector transparency results from policies, institutions, and practices that provide information to improve the understanding of public policy, increase policy effectiveness, reduce political uncertainty (Guillamón et al., 2011), and generate legitimacy for those actors and institutions involved in the public policy decisions.

Politically, prior work has tended to focus on the nature and competitiveness of intraparty politics in localities, as key to understanding when and why elected officials will choose to make information available. Although transparency is said to be a key to better governance, many political actors still have numerous reasons to resist being transparent (Berliner, 2014). Thus factors such as the proximity of measurement to an election, competitiveness of the election, presence of a dominant long term incumbent, and voter turnout have all been examined, as have differences in the level of commitment of left-affiliated and right-affiliated local governments. Local governments are led by people (politicians) whose personalities, leadership style, and ideology can influence how the municipality is managed (Guillamón et al., 2016). Gallego-Álvarez et al. (2010) showed that political ideology can have an impact on the development and dynamism of e-government. Indeed, García and García-García (2010) and Piotrowski and Van Ryzin (2007) also show that ideology is a determinant of transparency. Guillamón et al. (2011), del Sol (2013), Ferejohn (1999) and García-Sánchez et al. (2013) argue that left-wing parties are more transparent than right-wing parties, thereby indicating that leftist parties are more concerned about the ease of access to financial information and therefore demonstrate higher levels of transparency.

But additional studies do not support a consensus on this. In their study of 691 Catalan municipalities, Esteller-Moré and Otero (2012) conclude that political ideology does not seem to affect transparency, and Araújo and Tejedo-Romero (2016) conclude 
that right-wing parties contribute to greater transparency at the municipal level in Spain. Similarly, Tolbert et al. (2008) in their comparison of the fifty U.S. states argue that as right-wing governments are committed to reducing public spending, they are more likely to adopt e-government initiatives and therefore to release more information online, which suggests greater efficiency and reduced costs. Authors such as Guillamón et al. (2016) conclude that left-wing and right-wing governments disclose a similar amount of information. Lastly, Tejedo-Romero and Araújo (2018) clearly state that the level of local transparency is directly related to political factors, particularly in times of crisis; still, literature is inconclusive on the direction of ideology's effect on local transparency.

A final strand of research seeking to explain variation in levels of transparency, particularly computer mediated transparency, focuses directly or indirectly on the capacity of the government to carry out such mandates. The official website of a municipality has emerged as the most enduring forum for electronically hosting local government information, and this is generally understood to be an inexpensive way to deliver transparency, developing and maintaining such sites are not cost free (Jaeger and Bertot, 2010). Capacity is often measured in the literature in terms of the relative wealth of the municipality, the population size or density, internet usage/provision in the locality, and IT staffing (Tavares and da Cruz, 2020).

Scholars often use population size as a proxy for the capacity and modernity (Guillamón et al., 2016). del Sol (2013) finds that larger municipalities tending to have higher levels of transparency than smaller municipalities. In the same vein, Ryan et al. (2002), Giroux and McLelland (2003) and Moon (2002) show that large municipalities are more likely to disseminate financial information and to facilitate public access to that information. Moon (2002) also notes that larger municipalities are more proactive and strategic in developing e-government and concludes that the lack of personal, technical, 
and financial capacity is seen as one of the main barriers to e-government in many municipalities. By developing e-government, government websites become more informative and this enhances public management transparency. García and GarcíaGarcía (2010) argue in a subsequent study that large municipalities have more trained staff to develop a suitable site for citizens and to keep information up to date, whereas small municipalities often have to outsource these services and are reluctant to make such an investment. Moreover, site development can be considered a fixed cost and is therefore diluted in larger municipalities that benefit from economies of scale (Guillamón et al., 2016).

Not all authors have found a significant relationship between levels of disclosure and municipality size (Alt et al., 2006, Robbins and Austin, 1986, Dowley, 2006). And Esteller-Moré and Otero (2012) argue that smaller municipalities tend to provide more budgetary information and therefore achieve higher levels of budgetary transparency, and da Cruz et al. (2016, p. 883) conclude "that contrary to what one would expect, the largest cities are far from being the most transparent”. In seeking to capture the urban/rural effect, scholars have used population density as a proxy (Balk et al., 2018) and it was found that population density is positively associated with local government transparency via the Internet (Lowatcharin and Menifield, 2015), with budgetary transparency (Birskyte, 2019), and with disclosure of information in local government (Ortiz-Rodríguez et al., 2018). However, according to Piña and Avellaneda (2019) no clear rural/urban effect was identified. The contrasting findings from the above-mentioned works demonstrate the lack of consensus on the determinants of municipal transparency.

In fact, even if different local systems have evolved in the Member States of the European Union (centralised systems, decentralised systems and federal systems), observers have noted some inevitable subnational convergence over the past decade as a 
result of EU cohesion and regional development policy, and more recently, the EU wide financial crisis (Hoffman, 2018). Therefore, we suggest that the differences among local systems is less important in theorizing transparency efforts, and given that any transparency index developed in each country is developed in such a way, by local scholars and stakeholders, that the index itself already recognizes what it is that is different about each context. Thus the lessons drawn from a Portuguese analysis will likely yield lessons beyond Portugal, at least among EU member states.

\section{Portuguese Local Governance}

While Portugal is still considered a centralized and unitary state in the continental small European state tradition, local (municipal) government matters. Since the creation of a democratic local administration, with the adoption of the democratic constitution after the Carnation Revolution of 1974-1976, municipalities have been governed by the municipal assembly (Assembleia Municipal) that oversees (loosely) the activities of the executive branch, the municipal council (Câmara Municipal), which varies in size according to population. Most studies of transparency focus on the role of the municipal council and the mayor (Presidente da Câmara Municipal), head of the party list receiving the largest share of votes, presides over the executive council.

Despite considerable financial dependence on the center, municipal governments have responsibilities to execute and implement policies in many of the areas most important to citizens' daily lives: infrastructure, municipal transport, education, health and social welfare, housing, drainage and sanitation, promoting development, and safety. Elections are held every four years (last in 2017, next in 2021) and voters vote for a closed party list (or independent list) to elect the number of representatives each municipal council has to fill. Party competition at the national level involves a fairly two dimensional struggle between the party of the Left (Socialist Party) and the right 
(unusually named for European context) Social Democratic Party, but at the local level Greens, Communists, Left Bloc, Liberals, Conservatives and Independents also compete. Initial studies in Portugal highlight that transparency practices are still underdeveloped in local government in Portugal (da Cruz et al., 2016). In the aftermath of the financial crisis (in Portugal), and in response to the growing concern about the quality of local government and declining citizen involvement in local affairs, a decision was made to take measures to improve municipal transparency in Portugal. It was in this context that an official representative of Transparency International worked with a Portuguese NGO, Transparência e Integridade, Associação Cívica, to develop a project to assess the level of local governments' transparency through the analysis of the information available on the official municipality websites; the first assessment of Portugal's 308 municipalities was made in 2013 (da Cruz et al., 2016). Thus, the present study adopts the MTI definition of transparency, defined "as the act of providing relevant, credible, timely, intelligible, and easily accessible information about the format, performance, and management of the public good" (Transparency International Portugal, 2017, p. 7). Based on the review of the literature and theorizing about the sources of local government transparency as defined by MTI, we hypothesize the following:

Hypothesis 1. Partisan factors contribute to the explanation of the level of transparency of municipalities.

We will re-examine the relationship between ideology of party-aligned governments and scores on the MTI.

Hypothesis 2. A larger population in municipalities contributes positively to greater transparency. 
As a proxy for the capacity of local governments to deliver on promises of increased transparency, we hypothesize that larger municipalities will have the additional technical and personnel capacity to make greater strides in providing greater amounts of information on their webpages.

Hypothesis 3. The more indebted (per capita) municipalities are less transparent. As a measure of the political rationale for NOT providing transparency, we, like previous scholars, suggest that mayors presiding over heavily indebted municipalities will be less willing to publicize information that reflects on this vulnerability. There is debate in the literature about this, though, as García and García-García (2010), del Sol (2013), and Guillamón et al. (2011) conclude that fiscal variables such as local government debt are not relevant in determining the overall transparency index scores. However, Guillamón et al. (2016) and Polo-Otero (2011) find a negative relationship between levels of indebtedness and transparency, as do Alt and Lassen (2006) in their study of 19 OECD countries. We seek to resolve such disparities in the Portuguese case.

Hypothesis 4. Municipalities with a better financial efficiency have a higher level of transparency.

This hypothesis derives largely from agency theory, which suggests that as levels of revenue collection and transfers increase, so does public awareness and pressure (Ferejohn, 1999). In other words, the higher the taxes paid by citizens, the more pressure they can/will exert on local agents (politicians) for municipal transparency about how and where those tax revenues are being spent. In Italian municipalities, Galli et al. (2017) found a positive and high correlation between public spending performance and local transparency. Also Tavares and da Cruz (2020) concluded that the level of financial autonomy of Portuguese localities was positively associated with their level of 
transparency. We expect this relationship to hold over the longer period of time examined here.

Hypothesis 5. An increase in population density lead to a greater local transparency.

As noted in the literature review, prior research has shown a positive relationship between urban, densely populated areas and different aspects of government transparency (Lowatcharin and Menifield, 2015, Ortiz-Rodríguez et al., 2018, Birskyte, 2019).

\section{Operationalizing Variables and Research Design}

\section{Variables and data analysis}

To achieve the stated objectives, secondary data were collected from the following secondary sources: Transparency International in Portugal (dependent variable), Statistics Portugal (Instituto Nacional de Estatística - INE), and the National Elections Commission (independent variables). Based on a panel data model, the empirical analysis includes all 308 Portuguese municipalities over the time period 2013 to 2017. Our dependent variable is the MTI score of each municipality for each year. MTI is an index to measure local government transparency developed by academics and experts in Public Administration and promoted by International Transparency, which had its first academic appearance in 2015 in the Public Management Review (da Cruz et al., 2016).

The (MTI) is an index ${ }^{1}$ composed of 76 indicators that are grouped into the following seven dimensions (Transparency International - Portugal, 2017), scores for which range from 0 to 100 points::

\footnotetext{
${ }^{1}$ The overall MTI score ranges from 0 (municipalities with a low level of transparency) to 100 (municipalities with a high level of transparency).
} 
(1) Information about the organisation, social composition, and functioning of the municipality (18 indicators);

(2) Plans and reports (13 indicators);

(3) Taxes, fees, tariffs, prices, and regulations (5 indicators);

(4) Relationship with society (8 indicators);

(5) Public contracting (10 indicators);

(6) Economic and financial transparency (12 indicators);

(7) Transparency in the area of town planning (10 indicators).

Party affiliation (or its absence) of the mayors governing all municipalities were obtained from the National Elections Commission. Those governed by the Socialist Party, Communist Party, Left Bloc, Green Party, or coalitions between those party forces were considered left-wing (dummy variable with a value of 1). Municipalities governed by the Social Democratic Party, CDS-Populist Party, People's Monarchist Party, Earth Party, or coalitions between those party forces were considered right-wing, and coded zero ${ }^{2}$. We examine the results of both the 2009 municipal elections, held on October 11, which reflect the values of the dummy variables in 2013, and of the 2013 municipal elections, held on September 29, in which the dummy variable values affect 2014, 2015, 2016 and 2017.

Municipal debt per capita is a key pecuniary variable and is expressed in nominal values (in Euros). The population size reflects the number of inhabitants of a given municipality. The financial efficiency is measured by a ratio (municipal expenses/municipal revenues), where values below one (1) represent a financial surplus and values above one (1) represent a financial deficit. In other words, the efficiency ratio

\footnotetext{
${ }^{2}$ Municipalities governed by independent groups were considered missing values.
} 
represents the weight of municipal expenditure in terms of total municipal revenue. If municipal expenditure declines and municipal revenue increases, the ratio has a lower value and indicates greater efficiency. Population density reflects the number of human inhabitants per square kilometre in each municipal council.

Regarding quantitative data analysis, Table 1 provides the descriptive statistics of the dependent and explanatory variables.

\section{[Please, insert Table 1 about here]}

The values of MTI range from a minimum of 0.824286 points (municipal council of São Roque do Pico in 2015) to a maximum of 100 points in municipal council of Alfândega da Fé in 2016. The mean value is around 44 points. The higher the value of MIT the greater the municipal transparency level.

The municipal debt per capita is a continuous variable ranging from 0 euros (Penedono and Mealhada municipal councils in 2014) to 6771 euros (municipal council of Fornos de Algodres in 2013). This variable describes the municipal debt per inhabitant in euros in which the mean value is around 734 euros.

The population size is a discrete variable ranging from 459 inhabitants in Corvo (2014 and 2015) to 516815 inhabitants in the capital city, Lisbon (2013), and presents a mean value of 33600 inhabitants per municipal council.

Efficiency ratio ranges from 0.519740 points (municipal council of Castelo de Paiva) to 3.589164 points (municipal council of Vila Real de Santo António) and reflects a mean value of 0.951466 , which means that (on average) the revenues exceed the total expenses of the Portuguese municipalities. The higher the value of this variable the lower the local financial efficiency. 
Population density ranges from a minimal value of 4 persons per square kilometre in Alcoutim (2017) to a maximal value of approximately 7565 persons per square kilometre in Amadora (2017), with the mean municipality density of $292 \mathrm{p} / \mathrm{km}$.

Finally and as described before, political party is a dummy variable, but it is worth reporting that 140 municipal councils were governed by right-wing parties, 163 by leftwing parties and 5 others by independent mayors in 2013. Thereafter, in 2014, 2015, 2016 and 2017, 108 municipal councils were governed by right-wing parties, 187 municipal councils were governed by left-wing parties and the remaining 13 by independent groups/movements.

Moving on to some preliminary analysis of the variables included in this study, , and consistent with the reference values defined by Kline (2011) - $\mid$ Sk $\mid>3$ (marked asymmetry) or $|\mathrm{Ku}|$ values $>10$ (marked kurtosis) or $>20$ (very marked kurtosis), we note that none of the variables seriously violated the normal distribution. Finally, the missing values of the Political Party variable are explained by the absence of a left or right identified governing party (independent movements/independent mayors). Additionally, an evaluation of the variance inflation factors (VIFs) is a key element to detect multicollinearity between the explanatory variables. Table 2 shows the VIFs of the explanatory variables by presenting a diagnosis of collinearity.

\section{[Please, insert Table 2 about here]}

Table 2 shows the variance inflation factors below the thresholds proposed by Hair et al. (2013) (a value of 10 points as the recommended maximum VIF level). According to Table 2, there is no multicollinearity (or collinearity) between the explanatory variables. 


\section{Procedures}

The first differences in the variables were not included in our analysis as non-stationarity receives almost no attention in regression analyses with panel data (Phillips and Moon, 2000). In accordance with Hsiao (2014), the panel data have the advantage of increasing the degrees of freedom and reducing the problem of multicollinearity, which was tested by the VIF - please see Table 2. Despite these advantages, natural logarithms were also applied to the variables in the panel data model to eliminate heteroscedasticity. This procedure is in accordance with theoretical approaches (Gujarati and Porter, 2009) predicting that a log-log model can reduce heteroscedasticity more than a linear model.

The estimation method, namely ordinary least squares (OLS), generalised least squares (GLS), or least squares dummy variables (LSDV) might be eligible estimators for a static panel data model. The use of these estimators depends on the exogeneity hypothesis of the explanatory variables. The Durbin-Wu-Hausman test was used to ensure the consistency and efficiency of the estimators as follows:

$$
H=\left[\hat{b}_{I V}-\hat{b}_{O L S}\right]\left[\hat{b}_{I V}-\hat{b}_{O L S}\right]^{-1}\left[\hat{b}_{I V}-\hat{b}_{O L S}\right] \sim \chi_{k}^{2}
$$

In the case of explanatory endogenous variables, OLS, GLS or LSDV estimators show inconsistent and biased results (Wooldridge, 2015) and the instrumental variables (IVs) are widely used (Wooldridge, 2002, Han and Phillips, 2010). According to Larcker and Rusticus (2010), this practice has already been tested in the corporate governance and disclosure research areas. On the other hand, in a corporate governance research study Wintoki et al. (2012, p. 581) chose "to alleviate endogeneity concerns" by developing a dynamic panel data model; Lio et al. (2011) used the same method to study the relationship between internet and corruption. The Durbin-Wu-Hausman endogeneity test opens up all options to develop a static or a dynamic panel data model. 


\section{Econometric model and estimation options}

Based on F-test, Breusch-Pagan test and Hausman test, a fixed-effects model seems to be the best option. However, the Durbin-Wu-Hausman test has a significance level of 5\% and uses lagged levels of the regressors (one period); it shows that population size, efficiency ratio and political party are endogenous variables and municipal debt per capita is exogenous ${ }^{3}$. Even with endogeneity explanatory variables, a fixed-effects model would have been a possibility if the unobserved individual effect had been time-invariant (Wintoki et al., 2012). The theoretical framework of the fixed-effects option seeks to capture the heterogeneity under the assumption of strict exogeneity, which means that explanatory variables are not affected by any past or present changes in the dependent variable (e.g. MTI) (Schultz et al., 2010). Theoretically, this is not the case because the past/present MTI index may affect the current/future of some of the explanatory variables and therefore a fixed-effects regression may be biased (Wooldridge, 2002). This also justifies taking a dynamic approach to overcome the endogeneity issues arising from reverse causality (Ullah et al., 2018).

Thus, following Arellano and Bond (1991) we specify the following dynamic GMM model:

$\operatorname{lnMTI}_{i t}=\delta \ln M T I_{i t-1}+\beta_{1} \operatorname{lnMDebt}_{1, i t}+\beta_{2} \ln P S_{2, i t}+\beta_{3} \ln \left(\frac{M E x p}{M R}\right)_{3, i t}+\beta_{4} P P_{4, i t}+$
$\beta_{5} \ln P D_{5, i t}+\mu_{i}+\gamma_{t}+\varepsilon_{i t}$

in which $i$ represents the municipality, $t$ corresponds to the year, $\delta$ represents the adjustment coefficient, $\mu_{i}$ and $\gamma_{t}$ denote sets of municipalities dummies and time effects, and $\varepsilon_{i t}$ is the error term. The listed model assumes independence of the error term,

\footnotetext{
${ }^{3}$ Municipal debt per capita - Chi-square $(1)=0.183491$ with $\mathrm{p}$-value $=0.66839$; Population size - Chi-square $(1)=4.39405$ with $\mathrm{p}$-value $=0.0360645$; Efficiency ratio - Chi-square $(1)=9.64925$ with $p$-value $=0.00189428$; Political party - Chi-square $(1)=4.64942$ with $p$-value $=0.0310641$; Population density - Chi-square $(1)=6.56417$ with $\mathrm{p}$-value $=0.0104052$.
} 
identical distribution (normal), average zero (conditional) and the assumption of constant variance hypothesis. The dependent variable (MTI) assumes the logarithm form together with the following explanatory variables: (i) municipal debt per capita (MDebtpc), (ii) population size (PS), and (iii) efficiency ratio (MExp/MR). As mentioned earlier, political party (PP) is a dummy variable, and therefore, its binary form is maintained. MDebtpc is exogenous and the remaining explanatory variables were treated as endogenous variables, which are instrumented by their lagged levels.

The generalised method of moments (GMM) for small $T$ periods and large $N$ observations (Roodman, 2009) is perfectly adjusted to our panel data characteristics. Our approach is further justified by the fact that the majority of estimators developed in dynamic panel data models are based on GMM (Juodis and Sarafidis, 2018). Therefore, based on Arellano and Bond (1991) we performed difference GMM and the difference GMM estimator augmented by the Ahn and Schmidt (1995) nonlinear moment conditions, using the Stata (version 15.0) commands of xtdpd and xtdpdgmm, respectively. In line with the econometric approaches of Arellano and Bover (1995) and Blundell and Bond (1998), we also performed one-step system GMM and two-step system GMM estimations to obtain asymptotic efficiency gains of the additional orthogonality conditions - using the Stata commands of xtdpdsys and xtabond2, respectively. Additionally, to check the robustness of the results we run a two-way fixed effects model adding time dummies for each year in the regression.

\section{Results}

Assuming the dynamic panel data model previously specified, Table 3 shows the results of the estimations according to the modality of the estimator. 
Table 3 depicts consistent results across the five estimations. Overall, the statistically significant variables remain almost the same despite the use of different estimators, thus strengthening the consistency of the results. The consistency is strengthened by the confirmation that MTI is determined by its past level (MTI in the previous year), but the speed of adjustment is not clear as the results are quite different in all estimations. Notwithstanding the statistical significance of all estimations, the adjustment coefficients do not allow us to conclude how fast the adjustment is made between the optimal and actual MTI level.

Based on the regression results for the municipalities (Table 3), an increase in municipal debt per capita is associated with a decrease in the MTI, ceteris paribus. Additionally, an increase in the population of the municipalities is positively associated with MTI; everything else held constant. It can also be concluded that the municipalities governed by leftist parties are associated with an increase in the MTI, holding everything else constant. This political variable was a strong determinant of the MTI in different estimations. The efficiency ratio (MExp/MR) is always statistically significant and its negative sign was expected; this means that a stronger financial efficiency in the municipalities suggests greater transparency. The population density presents a lack of robustness throughout the estimations, and we do not find statistically significant results and consistence signals that allow us to identify a relationship between this variable and local transparency.

In summary, there is significant evidence supporting all research hypotheses, excluding the fifth one. 


\section{Discussion and Conclusions}

Firstly, and given one of the aims of the dynamic panel data model, it was not our intention to estimate the long-run propensity to local transparency or to test the speed of adjustment of MTI in the short-run. Instead, we chose to present different estimations to confirm both the consistency of our results and the statistical relevance of past MTI on its present level. Therefore, a critical discussion of the empirical results for the determinants of municipal transparency is important, even though they are in agreement with findings in previous studies.

In relation to political ideology, evidence are gathered to support hypothesis 1 . In fact, higher levels of transparency are found in municipalities governed by leftist parties. This finding corroborates the results of Guillamón et al. (2011), del Sol (2013), GarcíaSánchez et al. (2013), and Ferejohn (1999). Some authors assume that political ideology plays an important role in local transparency and that leftist governments a priori will tend to disseminate more information to gain the confidence of their citizens and obtain more resources with the ultimate goal of enlarging the public sector (Esteller-Moré and Otero, 2012, Ferejohn, 1999).

The direct relationship between population size and the MTI confirms the research trend in this area, which reveals a direct relationship between these variables (Lowatcharin and Menifield, 2015, Sičáková-Beblavá et al., 2016, Guillamón et al., 2011, Alcaraz-Quiles et al., 2014). Thus, hypothesis 2 is supported. Though a more careful investigation of the data suggests that the least transparent (lowest scoring) municipalities do tend to be concentrated among those that govern in the "autonomous" regions (archipelagos) of Madeira and the Azores, consistent with what da Cruz et al. (2016) referred to as a likely "island effect" in their first look at the first year of the MTI in 2013.

In relation to financial variables and in line with the works of Alt and Lassen (2006), Guillamón et al. (2016), and Polo-Otero (2011), the results show that there is a 
negative relationship between a municipality's debt (per capita) and its transparency index; that is, more indebted (per capita) municipalities are less likely to be transparent. Thus, hypothesis 3 is supported. However, authors such as del Sol (2013) have observed that debt is not relevant in terms of the transparency of municipalities. This discrepancy in the conclusions may be explained by the socioeconomic differences between the countries studied.

Furthermore, the results confirmed that a weaker financial efficiency contribute to lower transparency. In other words, it can be said that greater financial efficiency in municipalities leads to greater local transparency and therefore hypothesis 4 is supported. This is in line with conclusions presented in some other recent studies (Tavares and da Cruz, 2020, Galli et al., 2017). On the one hand, this might reveal that the higher the taxes paid by citizens, the more pressure they can/will exert on local agents (politicians); on the other hand, a financial surplus of municipal councils might enhance their resources to foster transparency policies toward local taxpayers.

Additionally, population density was not a statistically significant predictor of local transparency. The available evidence does not support hypothesis 5 , in contrast to prior findings that suggested urban status favours local transparency (Lowatcharin and Menifield, 2015, Ortiz-Rodríguez et al., 2018), thorough our findings are supported by other academics (Piña and Avellaneda, 2019).

The main objective of this article was to identify some specific factors that explain continued variation in the efforts of municipal governments to promote greater transparency about their work via the municipal webpage. Overall, the agency relationship between politicians and voters in the context of the MTI is not uniform across Portugal. In terms of local transparency, this study therefore confirms the extensive agency problem in some municipalities, as evident from the various levels of transparency 
are found in the territory. The decentralisation of powers to local government has raised concerns and increased national and international interest in increasing transparency at the local level.

While this study sheds light on important determinants of the variation in local government transparency, we acknowledge the likely importance of some alternative political variables. Future lines of research should introduce a larger group of political determinants, such as electoral competitiveness, the strength of civil society or media presence in the district and more detailed assessment of the political context (in addition to the competitiveness of municipal elections, length of time the mayor has been in office, voter turnout). Additionally, future work on the differences on local transparency level between independent governments and party-aligned governments might be explored, as well as why MTI in municipal councils from Portuguese islands are almost 10 points below (on average) the mean value for all Portuguese municipal councils. It would be worth examining cross nationally whether similar island effects are observed in other European countries.

In general, these findings raise policy makers' awareness of some characteristics that influence the level of municipalities' transparency and can therefore serve as a starting point for the implementation of policy measures addressing local transparency. Furthermore, within the scope of the ongoing transfer of jurisdictions to local authorities and inter-municipal entities until 2022 (under Law no. 50/2018), this study sheds light on specific municipal characteristics that can influence transparency and which have implications for the wider European context, given the gradual horizontal diffusion of EU norms and principles of good governance. 


\section{References}

Ahn, S. C. \& Schmidt, P. 1995. Efficient estimation of models for dynamic panel data. Journal of Econometrics, 68, 5-27.

Alcaraz-Quiles, F. J., Navarro-Galera, A. \& Ortiz-Rodríguez, D. 2014. Factors influencing the transparency of sustainability information in regional governments: an empirical study. Journal of Cleaner Production, 82, 179-191.

Alt, J. E. \& Lassen, D. D. 2006. Fiscal transparency, political parties, and debt in OECD countries. European Economic Review, 50, 1403-1439.

Alt, J. E., Lassen, D. D. \& Rose, S. 2006. The Causes of Fiscal Transparency: Evidence from the U.S. States. IMF Staff Papers, 53, 30-57.

Araújo, J. F. F. E. D. \& Tejedo-Romero, F. 2016. Local government transparency index: determinants of municipalities' rankings. International Journal of Public Sector Management, 29, 327-347.

Arellano, M. \& Bond, S. 1991. Some tests of specification for panel data: Monte Carlo evidence and an application to employment equations. Review of Economic Studies, 58, 277-297.

Arellano, M. \& Bover, O. 1995. Another look at the instrumental variable estimation of error-components models. Journal of Econometrics, 68, 29-51.

Armstrong, E. 2005. Integrity, transparency and accountability in public administration: Recent trends, regional and international developments and emerging issues. United Nations, Department of Economic and Social Affairs, 1-10.

Balk, D., Leyk, S., Jones, B., Montgomery, M. R. \& Clark, A. 2018. Understanding urbanization: A study of census and satellite-derived urban classes in the United States, 1990-2010. PloS one, 13, 1-20.

Batalha, S. a. A. 2014. Determinantes da Transparência Municipal em Portugal: Uma Análise Empírica. Dissertação de Mestrado em Economia e Políticas Públicas, Instituto Superior de Economia e Gestão.

Berliner, D. 2014. The Political Origins of Transparency. The Journal of Politics, 76, 479-491.

Berry, F. S., Brower, R. S., Sang Ok, C., Goa, W. X., Heesoun, J., Myungjung, K. \& Word, J. 2004. Three Traditions of Network Research: What the Public Management Research Agenda Can Learn from Other Research Communities. Public Administration Review, 64, 539-552.

Birskyte, L. 2019. Determinants of Budget Transparency in Lithuanian Municipalities. Public Performance \& Management Review, 42, 707-731.

Blundell, R. \& Bond, S. 1998. Initial conditions and moment restrictions in dynamic panel data models. Journal of Econometrics, 87, 115-143.

Cooper, T. L. 2004. Big Questions in Administrative Ethics: A Need for Focused, Collaborative Effort. Public Administration Review, 64, 395-407.

Cuadrado-Ballesteros, B., Frías-Aceituno, J. \& Martínez-Ferrero, J. 2014. The role of media pressure on the disclosure of sustainability information by local governments. Online Information Review, 38, 114-135.

Curtin, D. \& Meijer, A. J. 2006. Does transparency strengthen legitimacy? Information polity, 11, 109-122.

Da Cruz, N. F. \& Marques, R. C. 2014. Scorecards for sustainable local governments. Cities, 39, 165-170.

Da Cruz, N. F., Tavares, A. F., Marques, R. C., Jorge, S. \& De Sousa, L. 2016. Measuring Local Government Transparency. Public Management Review, 18, 866-893. 
De Fine Licht, J., Naurin, D., Esaiasson, P. \& Gilljam, M. 2014. When Does Transparency Generate Legitimacy? Experimenting on a Context-Bound Relationship. Governance, 27, 111-134.

Del Sol, D. A. 2013. The institutional, economic and social determinants of local government transparency. Journal of Economic Policy Reform, 16, 90-107.

Dowley, K. M. 2006. Local government transparency in East Central Europe. Local Government Studies, 32, 563-583.

Esteller-Moré, A. \& Otero, J. P. 2012. Fiscal Transparency: (Why) does your local government respond? Public Management Review, 14, 1153-1173.

Ferejohn, J. 1999. Accountability and Authority: Toward a Theory of Political Accountability. In A. Przeworski, S.C. Stokes, and B. Manin, eds. Democracy, accountability and representation. Cambridge University Press, 131-153.

Gallego-Álvarez, I., Rodríguez-Domínguez, L. \& García-Sánchez, I.-M. 2010. Are determining factors of municipal E-government common to a worldwide municipal view? An intra-country comparison. GOVERNMENT INFORMATION QUARTERLY, 27, 423-430.

Galli, E., Rizzo, I. \& Scaglioni, C. 2017. Transparency, quality of institutions and performance in the Italian Municipalities. ISEG-Lisbon School of Economics and Management, Department of Economics ....

García-Sánchez, I.-M., Frías-Aceituno, J.-V. \& Rodríguez-Domínguez, L. 2013. Determinants of corporate social disclosure in Spanish local governments. Journal of Cleaner Production, 39, 60-72.

García, A. C. \& García-García, J. 2010. Determinants of Online Reporting of Accounting Information by Spanish Local Government Authorities. Local Government Studies, 36, 679-695.

Giroux, G. \& Mclelland, A. J. 2003. Governance structures and accounting at large municipalities. Journal of Accounting and Public Policy, 22, 203-230.

Grimmelikhuijsen, S. G. \& Welch, E. W. 2012. Developing and Testing a Theoretical Framework for Computer-Mediated Transparency of Local Governments. Public Administration Review, 72, 562-571.

Guillamón, M.-D., Bastida, F. \& Benito, B. 2011. The Determinants of Local Government's Financial Transparency. Local Government Studies, 37, 391-406.

Guillamón, M.-D., Ríos, A.-M., Gesuele, B. \& Metallo, C. 2016. Factors influencing social media use in local governments: The case of Italy and Spain. Government Information Quarterly, 33, 460-471.

Gujarati, D. N. \& Porter, D. C. 2009. Basic Econometrics, McGraw-Hill Irwin.

Hair, J. F., Black, W. C., Babin, B. J. \& Anderson, R. E. 2013. Multivariate Data Analysis, Pearson Education Limited.

Han, C. \& Phillips, P. C. B. 2010. GMM Estimation for Dynamic Panels with Fixed Effects and Strong Instruments at Unity. Econometric Theory, 26, 119-151.

Hoffman, I. 2018. Some Thoughts on the Administration of the Regional Development in the Member States of the EU - In the Light of the Role of the Municipal Bodies 1. Central European Public Administration Review, 16, 7-29.

Hsiao, C. 2014. Analysis of Panel Data, Cambridge, Cambridge University Press.

Jaeger, P. T. \& Bertot, J. C. 2010. Transparency and technological change: Ensuring equal and sustained public access to government information. Government Information Quarterly, 27, 371-376.

Jensen, M. C. \& Meckling, W. H. 1976. Theory of the firm: Managerial behavior, agency costs and ownership structure. Journal of Financial Economics, 3, 305360. 
Juodis, A. \& Sarafidis, V. 2018. Fixed T dynamic panel data estimators with multifactor errors. Econometric Reviews, 37, 893-929.

Kline, R. B. 2011. Principles and practice of structural equation modeling, New York, Guilford Press.

Kraay, A. \& Kaufmann, D. 2002. Growth Without Governance. Policy Research Working Papers, World Bank, 2928, 1-50.

Larcker, D. F. \& Rusticus, T. O. 2010. On the use of instrumental variables in accounting research. Journal of Accounting and Economics, 49, 186-205.

Lio, M.-C., Liu, M.-C. \& Ou, Y.-P. 2011. Can the internet reduce corruption? A crosscountry study based on dynamic panel data models. Government Information Quarterly, 28, 47-53.

Lowatcharin, G. \& Menifield, C. E. 2015. Determinants of Internet-enabled Transparency at the Local Level:A Study of Midwestern County Web Sites. State and Local Government Review, 47, 102-115.

Moon, M. J. 2002. The Evolution of E-Government among Municipalities: Rhetoric or Reality? Public Administration Review, 62, 424-433.

Oecd 2002. OECD Best Practices for Budget Transparency. OECD Publications Service. Paris: OECD.

Ortiz-Rodríguez, D., Navarro-Galera, A. \& Alcaraz-Quiles, F. J. 2018. The Influence of Administrative Culture on Sustainability Transparency in European Local Governments. Administration \& Society, 50, 555-594.

Phillips, P. C. B. \& Moon, H. R. 2000. Nonstationary panel data analysis: an overview of some recent developments. Econometric Reviews, 19, 263-286.

Piña, G. \& Avellaneda, C. 2019. Central Government Strategies to Promote Local Governments' Transparency: Guidance or Enforcement? Public Performance \& Management Review, 42, 357-382.

Piotrowski, S. J. \& Van Ryzin, G. G. 2007. Citizen Attitudes Toward Transparency in Local Government. The American Review of Public Administration, 37, 306323.

Polo-Otero, J. 2011. Análisis de los determinantes de la transparencia fiscal: evidencia empírica para los municipios catalanes. Revista de Economía del Caribe.

Putnam, R. D. 1993. What makes democracy work? National Civic Review, 82, 101 107.

Robbins, W. A. \& Austin, K. R. 1986. Disclosure Quality in Governmental Financial Reports: An Assessment of the Apropriateness of a Compound Measure. Journal of Accounting Research 24, 412-421.

Roodman, D. 2009. How to do Xtabond2: An Introduction to Difference and System GMM in Stata. The Stata Journal, 9, 86-136.

Ryan, C., Stanley, T. \& Nelson, M. 2002. Accountability Disclosures by Queensland Local Government Councils: 1997-1999. Financial Accountability \& Management, 18, 261-289.

Schultz, E. L., Tan, D. T. \& Walsh, K. D. 2010. Endogeneity and the corporate governance-performance relation. Australian journal of Management, 35, 145163.

Sičáková-Beblavá, E., Kollárik, M. \& Sloboda, M. 2016. Exploring the Determinants of Transparency of Slovak Municipalities. NISPAcee Journal of Public Administration and Policy, 9, 121-145.

Sjöberg, C. 2010. Factors influencing transparency in public institutions: An analysis of Chilean municipalities. B.A Thesis in Political Science. Gothenburg, Sweden: University of Gothenburg. 
Tavares, A. F. \& Da Cruz, N. F. 2020. Explaining the transparency of local government websites through a political market framework. Government Information Quarterly, 37, 1-13.

Tejedo-Romero, F. \& Araújo, J. F. F. E. D. 2018. Determinants of Local Governments' Transparency in Times of Crisis: Evidence From Municipality-Level Panel Data. Administration \& Society, 50, 527-554.

Tejedo-Romero, F. \& Araújo, J. F. F. E. D. 2020. E-government-enabled transparency: The effect of electoral aspects and citizen's access to Internet on information disclosure. Journal of Information Technology \& Politics, 17, 268-290.

Tolbert, C. J., Mossberger, K. \& Mcneal, R. 2008. Institutions, Policy Innovation, and E-Government in the American States. Public Administration Review, 68, 549563.

Transparency International - Portugal 2017. Índice de Transparência Municipal: Apresentação e Indicadores. Lisboa: Transparência e Integridade, Associação Cívica.

Ullah, S., Akhtar, P. \& Zaefarian, G. 2018. Dealing with endogeneity bias: The generalized method of moments (GMM) for panel data. Industrial Marketing Management, 71, 69-78.

Wintoki, M. B., Linck, J. S. \& Netter, J. M. 2012. Endogeneity and the dynamics of internal corporate governance. Journal of Financial Economics, 105, 581-606.

Wooldridge, J. M. 2002. Econometric Analysis of Cross Section and Panel Data, Massachusetts, MIT Press.

Wooldridge, J. M. 2015. Introductory Econometrics: A Modern Approach, Boston, Cengage Learning. 
Table 1. Descriptive statistics using the 1:1-308: 5 observations (missing values were ignored)

\begin{tabular}{|l|l|l|l|l|}
\hline Variable & Mean & Median & Minimum & Maximum \\
\hline MTI $^{1}$ & 44.3106 & 40.7932 & 0.824286 & 100.000 \\
\hline MDebtpc $^{2}$ & 733.671 & 526.500 & 0.00000 & 6671.00 \\
\hline EffRatio $^{3}$ & 0.951466 & 0.935078 & 0.519740 & 3.58916 \\
\hline PS $^{4}$ & 33600.0 & 14347.0 & 459.000 & 516815 \\
\hline PP $^{5}$ & 0.61430 & 1.00000 & 0.000000 & 1.00000 \\
\hline PD & 291.980 & 68.7000 & 4.00000 & 7565.40 \\
\hline Variable & $\begin{array}{l}\text { Standard } \\
\text { deviation }\end{array}$ & $\mathbf{C V}$ & Asymmetry & Kurtosis \\
\hline MTI & 17.7345 & 0.400231 & 0.572345 & -0.0493258 \\
\hline MDebtpc & 747.007 & 1.01818 & 3.19203 & 14.4987 \\
\hline EffRatio & 0.154055 & 0.161914 & 5.69464 & 71.5931 \\
\hline PS & 54763.8 & 1.62987 & 4.24064 & 25.1077 \\
\hline PP & 0.48693 & 0.79266 & -0.46962 & -1.7795 \\
\hline PD & 795.868 & 2.72577 & 5.64824 & 37.3042 \\
\hline Variable & $\mathbf{5}^{\text {th }}$ percentile & $\mathbf{9 5}$ th percentile & $\begin{array}{l}\text { Interquartile } \\
\text { range }\end{array}$ & Missing values \\
\hline MTI & 19.7841 & 78.5714 & 23.8364 & 0 \\
\hline MDebtpc & 125.050 & 2118.85 & 569.250 & 0 \\
\hline EffRatio & 0.784803 & 1.16441 & 0.110716 & 0 \\
\hline PS & 3230.30 & 140832. & 29584.7 & 0 \\
\hline PP & 0.000000 & 1.00000 & 1.00000 & 57 \\
\hline PD & 9.70000 & 1400.44 & 151.275 & 0 \\
\hline & & & & \\
\hline
\end{tabular}

\footnotetext{
${ }^{1}$ MTI: Municipal transparency index

${ }^{2}$ MDebtpc: Municipal debt per capita

${ }^{3}$ EffRatio: Efficiency ratio

${ }^{4}$ PS: Population size

${ }^{5}$ PP: Political party

${ }^{6}$ PD: Population density
} 
Table 2. Diagnosis of collinearity

\begin{tabular}{|l|l|}
\hline Variable & VIF \\
\hline EffRatio & 1.006 \\
\hline MDebtpc & 1.090 \\
\hline PS & 2.896 \\
\hline PP & 1.009 \\
\hline PD & 2.769 \\
\hline
\end{tabular}


Table 3. Results from the estimations

\begin{tabular}{|c|c|c|c|c|c|}
\hline $\begin{array}{l}\text { Explanatory variables } \\
\text { and time dummies }\end{array}$ & $\begin{array}{l}\text { One-step sys } \\
\text { GMM }\end{array}$ & $\begin{array}{l}\text { Two-step sys } \\
\text { GMM }\end{array}$ & $\begin{array}{l}\text { Fixed-effects with } \\
\text { time dummies }\end{array}$ & Diff-GMM & $\begin{array}{l}\text { Diff-GMM } \\
\text { augmented }\end{array}$ \\
\hline $\ln M T I_{i t,-1}$ & $\begin{array}{l}0.388 * * * \\
(0.044)\end{array}$ & $\begin{array}{l}0.514 * * * \\
(0.029)\end{array}$ & ---- & --- & $\begin{array}{ll}--- \\
\end{array}$ \\
\hline$\Delta \ln M T I_{i t,-1}$ & ---- & --- & ---- & $\begin{array}{l}0.460 * * * \\
(0.087)\end{array}$ & $\begin{array}{l}0.392 * * * \\
(0.044)\end{array}$ \\
\hline Constant & $\begin{array}{l}8.803 * * * \\
(1.346)\end{array}$ & $\begin{array}{l}5.149 * * * \\
(1.159)\end{array}$ & $\begin{array}{l}-71.479 \\
(46.606)\end{array}$ & $\begin{array}{l}8.680 * * * \\
(2.702)\end{array}$ & $\begin{array}{l}9.284 * * * \\
(1.314)\end{array}$ \\
\hline ln MDebtpc & $\begin{array}{l}-0.651 * * * \\
(0.092)\end{array}$ & $\begin{array}{l}-0.232 * * * \\
(0.043)\end{array}$ & $\begin{array}{l}0.022 \\
(0.046) \\
\end{array}$ & $\begin{array}{l}-1.086 * * * \\
(0.230)\end{array}$ & $\begin{array}{l}-0.671 * * * \\
(0.099)\end{array}$ \\
\hline $\ln$ (Expenses / Revenues) & $\begin{array}{l}-1.576^{*} \\
(0.912) \\
\end{array}$ & $\begin{array}{l}-2.612 * * * \\
(0.950)\end{array}$ & $\begin{array}{l}0.140 \\
(0.733)\end{array}$ & $\begin{array}{l}-4.723 * \\
(2.451) \\
\end{array}$ & $\begin{array}{l}-1.901 * * \\
(0.745)\end{array}$ \\
\hline $\ln \mathrm{PS}$ & $\begin{array}{l}0.106^{* * *} \\
(0.027)\end{array}$ & $\begin{array}{l}0.100 * \\
(0.060)\end{array}$ & $\begin{array}{l}15.335 * \\
(8.611)\end{array}$ & $\begin{array}{l}0.928^{* * *} \\
(0.201)\end{array}$ & $\begin{array}{l}0.112 * * * \\
(0.028)\end{array}$ \\
\hline $\ln \mathrm{PD}$ & $\begin{array}{l}0.019 \\
(0.012)\end{array}$ & $\begin{array}{l}0.073 * \\
(0.039)\end{array}$ & $\begin{array}{l}-17.069 * * \\
(8.598)\end{array}$ & $\begin{array}{l}-0.021 \\
(0.014)\end{array}$ & $\begin{array}{l}0.021 \\
(0.026)\end{array}$ \\
\hline $\mathrm{PP}$ & $\begin{array}{l}0.090 * * * \\
(0.022)\end{array}$ & $\begin{array}{l}0.120 * * \\
(0.060)\end{array}$ & $\begin{array}{l}0.154 * * * \\
(0.052)\end{array}$ & $\begin{array}{l}0.148^{*} \\
(0.250)\end{array}$ & $\begin{array}{l}0.092 * * * \\
(0.022)\end{array}$ \\
\hline \multicolumn{6}{|l|}{ Time dummies } \\
\hline 2014 & ---- & $\begin{array}{ll}--- \\
\end{array}$ & $\begin{array}{l}-0.028 \\
(0.024)\end{array}$ & ---- & \\
\hline 2015 & ---- & ---- & $\begin{array}{l}0.170 * * * \\
(0.029)\end{array}$ & ---- & \\
\hline 2016 & ---- & ---- & $\begin{array}{l}0.312 * * * \\
(0.037)\end{array}$ & $\begin{array}{c}--- \\
\end{array}$ & \\
\hline
\end{tabular}




\begin{tabular}{|c|c|c|c|c|c|}
\hline 2017 & ---- & ---- & $\begin{array}{l}0.281 * * * \\
(0.040)\end{array}$ & ---- & \\
\hline \multicolumn{6}{|c|}{ Statistical robustness } \\
\hline Observations & 1180 & 1180 & 1483 & 1180 & 1180 \\
\hline Instruments/moment & 14 & 60 & 0 & 26 & 14 \\
\hline AR (1) & $\begin{array}{l}\mathrm{z}=-7.62 \\
P \text {-value }=0.000\end{array}$ & $\begin{array}{l}\mathrm{z}=-4.71 \\
P \text {-value }=0.000\end{array}$ & ---- & $\begin{array}{l}\mathrm{z}=-4.43 \\
P \text {-value }=0.000\end{array}$ & $\begin{array}{l}\mathrm{z}=-3.88 \\
P \text {-value }=0.0001\end{array}$ \\
\hline AR (2) & $\begin{array}{l}\mathrm{z}=-0.68 \\
P \text {-value }=0.499\end{array}$ & $\begin{array}{l}\mathrm{z}=-0.24 \\
P \text {-value }=0.807\end{array}$ & ---- & $\begin{array}{l}Z=1.07 \\
P \text {-value }=0.285\end{array}$ & $\begin{array}{l}\mathrm{z}=-0.40 \\
P \text {-value }=0.6880\end{array}$ \\
\hline
\end{tabular}

Note: Standard errors within parentheses. ${ }^{*} \mathrm{p}<.10 ; * * \mathrm{p}<.05 ;{ }^{* * *} \mathrm{p}<.01$. 